\title{
CONTINUOUS FEMORAL NERVE BLOCK VERSUS FASCIA ILIACA COMPARTMENT BLOCK AS POSTOPERATIVE ANALGESIA IN PATIENTS WITH HIP FRACTURE
}

\author{
Marina Temelkovska-Stevanovska ${ }^{1}$, Vesna Durnev ${ }^{1}$, Marija Jovanovski-Srceva ${ }^{1}$, \\ Maja Mojsova-Mijovska ${ }^{1}$, Sime Trpeski
}

${ }^{1}$ Univeristy Anesthesia, Reanimation and Intensive Care Clinic, Medical Faculty, Ss. Cyril and Methodius University, Skopje, R. Macedonia

${ }^{2}$ Univeristy Traumatology Clinic, Medical Faculty, Ss. Cyril and Methodius University, Skopje, R. Macedonia

Corresponding Author: Marina Temelkovska Stevanovska, Anesthesia, Reanimation and Intensive Care Clinic, Medical Faculty, Ss Cyril and Methodius University, 1000 Skopje, R. Macedonia, Tel. + 389 (0)2 70349943 , E-mail: matest@t-home.mk

\begin{abstract}
Introduction: Systemic postoperative analgesia is inefficient in most patients with hip fracture, which is the reason for pain, especially during leg movement. Peripheral and plexus nerve blocks are an efficient option for postoperative pain relief.

The aim of this study was to compare the effect and duration of continuous FNB versus a single FIC block as a postoperative analgesia in patients with hip fracture.

Methods: Sixty patients with hip fracture were included and were randomly assigned to two groups of 30 patients: FNB group - patients with continuous femoral nerve block; and FIC group -patients with a single fascia iliaca compartment block. In all patients, pain intensity was measured at rest and in passive leg movement by using VDS (0-4) at several intervals: 1, 2, 12, 24, 36 and 48 hours after intervention. The amount of supplemental analgesia was measured, together with the time when the patient needed it for the first time, as well as the side effects.

Results: The values of VDS were significantly lower in patients with FNB block versus patients with FIC block in rest and movement at the 24 -hour intervals ( $46.67 \%$ vs $0 \%$ felt moderate pain), after 36 hours $(43.33 \%$ vs $0 \%$ felt moderate pain) and 48 hours after intervention $(46.67 \%$ vs $3.33 \%$ felt moderate to severe pain) for $\mathrm{p}<0.05$. Patients with FNB block received a significantly lower amount of supplemental analgesia, $23.3 \%$ of the FNB group vs 50\% of the FIC group $(\mathrm{p}<0.05)$. Registered side effects were were nausea, dizziness and sedation, and they were statistically significantly more frequent in the FIC group $(\mathrm{p}<0.05)$.

Conclusion: Pain relief in the postoperative period was superior in the FNB group versus the FIC group at rest and in movement in patients with hip fracture.
\end{abstract}

Key words: postoperative analgesia, regional anaesthesia, fascia iliaca compartment block, femoral nerve block, hip fracture.

\section{Introduction}

Hip fractures occur most commonly in elderly individuals as a result of minimal trauma and vertical falls [1]. Hip fractures cause significant pain in the preoperative and post- operative period, which increases in an attempt to move the injured or operated leg [2]. Early mobilization and early commencement of physical therapy are important factors to reduce postoperative morbidity and mortality in el- 
derly patients [3]. This is why in this age group of patients an adequate postoperative analgesia is necessary. Uncontrolled acute pain in elderly patients can cause heart, lung and endocrine disorders. Trauma and pain induce "a complex response to stress", which is characterized by hormonal and inflammatory changes that lead to immunosuppression [4]. Effective analgesia in patients greatly modifies the pathophysiological response to stress, prevents or reduces postoperative complications and improves patient recovery [5].

Systemic analgesia is a commonly used method of treating acute pain, as well as postoperative treatment of a hip fracture. For this purpose, a combination of opioid analgesics, paracetamol and non-steroidal anti-inflammatory drugs (NSAIDs) is most widely used [6].

Opioids are effective analgesics, but it is difficult to titrate safe and effective doses in elderly patients. Elderly patients require lower doses of opioids compared to young patients [7]. Thus for their careful titration it is necessary to avoid unwanted side effects such as: increased sedation, confusion, nausea, vomiting, ileus, hypotension, and respiratory depression [8].

Most commonly used nonopioid analgesics for the treatment of painful syndromes are non-steroidal anti-inflammatory drugs. They have no side-effects as do opioid analgesics, but can cause damage to the gastrointestinal mucosa, renal tubules and platelet dysfunction, and can increase intraoperative bleeding $[9,10]$.

Systematic analgesia in the postoperative period is unsatisfactory in the majority of hip fracture patients, which is a cause of pain when attempting to move an operated leg, and provokes dissatisfaction among patients during the postoperative recovery [11].

Nerves and neural plexus blocks are efficient and, depending on the surgery, a specific choice for postoperative analgesia [12]. The hip has complex innervations consisting of lumbar and sacral plexus branches. Lumbar plexus block and blocks of its branches provide excellent analgesia. Blocking plexus lumbalis is performed by rear paravertebral (psoas compartment block) and anterior inguinal paravascular access (n. femoralis block, known as the "3-in-1" block) [13]. An anterior approach provides a simultaneous blockade of $n$. femoralis, $n$. cutaneus femoris lateralis and $n$. Obturatorius; therefore, this technique is called " 3 -in-1". This approach provides $100 \%$ blockade of the femoral nerve [14, 15]. Femoral nerve block can be done with a single application of a local anaesthetic and thus provides satisfactory analgesia [16]. However, its time-duration may vary. Because of this, the continuous technique is more commonly used by placing a catheter through the needle which induces the nerve block. This enables continuous or intermittent application of a local anaesthetic near the blocked nerve and can achieve a long block of the corresponding nerve [17, 18]. An anterior inguinal paravascular approach belongs to the group of superficial blocks and it has a low complication incidence. Therefore, it is considered a safe method for postoperative analgesia $[17,18]$. Using a peripheral nerve stimulator or ultrasound is recommended [19].

A fascia iliaca compartment block is a modification of the femoral nerve block. It is performed by application of a great amount of local anaesthetic beneath the fascia iliaca and provides a block of $n$. femoralis and n. cutaneus femoris lateralis and rarely of $n$. obturatorius $[20,21]$. It is a very simple procedure to perform this block; there are almost no complications and hence this procedure belongs to the small group of blocks that need no nerve stimulator or ultrasound [22-24]. Although it is simpler in comparison to femoral nerve block, the authors who have experience in performing peripheral block consider it a second choice [25]. It is recommended to be used if there is no peripheral nerve stimulator available [26].

The aim of this study was to compare the quality and duration of postoperative analgesia between the two different approaches of femoral nerve block (continuous femoral nerve block vs. single fascia iliaca compartment block) in patients with hip fracture.

\section{Material and methods}

This study was conducted as a prospective, randomized, controlled clinical study at the University Traumatology, Orthopedics, Anesthesia, Reanimation and Intensive Care 
Clinic and the Urgent Centre in Skopje, in the period from November 2012 to November 2013. Ethical approval was granted by the Clinical Research Ethics Committee of the University Traumatology, Orthopedics, Anesthesia, Reanimation and Intensive Care Clinic and the Urgent Centre, Skopje, and the Ethics Committee of the Faculty of Medicine, Skopje. Informed consent was obtained from every patient.

Inclusion criteria for the study:

The study included 60 patients older than 65 years and ASA I-IV, surgically treated due to extracapsular hip fracture (fracture femoris pertrochanterica, fractura femoris subtrochanterica, fractura basocervicalis femoris - for a fixation with DHS or DCS plate).

Exclusion criteria for the study:

- Malignancy;

- Dementia / confusion;

- History of coagulopathies;

- Local anaesthetic allergy or allergy to tramadol;

- Local inguinal area infection where block was intended to be performed.

Preoperatively, the following demographic characteristics were registered in all patients: age, gender, body weight ( $\mathrm{kg})$, ASA status (classification according to the American Society of Anaesthesiologists), duration of surgery, and diagnosis (fractura femoris pertrochanterica, fractura femoris subtrochanterica, fractura basocervicalis femoris). Two hours before surgery patients were sedated with $5 \mathrm{mg}$ diazepam. The surgery was performed under spinal anaesthesia with 2.5 to $3 \mathrm{ml} 0.5 \%$ bupivacaine in L2-L3 or L3-L4 - intervertebral space. ECG, heart rate, peripheral oxygen saturation and non-invasive pressure were intraoperatively routinely monitored. After surgery, patients were randomly divided into 2 groups, each one consisting of 30 patients, depending on the method of postoperative analgesia: FNB group - patients postoperatively pain-released with continuous femoral nerve block and FIC group - patients postoperatively pain-released with a single fascia iliaca compartment block. Shortly after surgery and performing the blocks, patients were transported into the Recovery Room for 2 hours. Once the patients were pain released, they were transported to the Traumatology Unit.
Continuous femoral nerve block was performed immediately after surgery in the FNB group. The block was performed in the operating theatre by using the existing routine monitoring (ECG, heart rate, peripheral oxygen saturation, and non-invasive pressure). Contiplex D Set: $50 \mathrm{~mm}$ long, $18 \mathrm{G}$ insulated stimulation needles with PTFE catheter guide and a peripheral nerve stimulator were used to perform this block, while the patient was in a supine position. Bupivacaine of $0.25 \%, 20 \mathrm{ml}$, was applied after negative aspiration of blood. Constant infusion of bupivacaine of $0.25 \%$ was continued with 0.1 $\mathrm{ml} / \mathrm{kg} / \mathrm{h}$ during the next 48 hours.

A single fascia iliaca compartment block was performed immediately after surgery in the FIC group, in the operating theatre with the previously used monitoring. A Stimuplex D 50 mm long, top blunted "bullet - type" 22 G needle was used for performing this block. A peripheral nerve stimulator was not used. The patient was again in a supine position. Bupivacaine of $0.25 \%, 40 \mathrm{ml}$, was applied, once, after previously performed aspiration test.

The degree of analgesia was monitored during the first 48 hours postoperatively in patients from both groups and was assessed by using the Verbal Descriptive Scale (0 - without pain, 1 - moderate, 2 - moderate to severe, 3 severe, and 4 - unbearable pain). The degree of analgesia was assessed at rest and during passive flexion of the hip, 1 to 2 hours after surgery, in the Recovery Room. The evaluation of the analgesia degree continued at intervals of 12 , 24, 36 and 48 hours, in the Traumatology Unit.

If the patient felt pain despite the applied analgesia (VDS > 1), tramadol of $1 \mathrm{mg} / \mathrm{kgbw} / \mathrm{iv}$ was supplied additionally. The time of the patient's first request for additional analgesia was registered, as well as additional quantities of given opioid analgesic, during the first and second postoperative day (POD1 and POD2).

Consecutive side-effects (hypotension, nausea, vomiting, sedation, dizziness, haematoma, infection, catheter impassibility, and signs of local anaesthetic toxicity) were noted, too.

\section{Statistical analyses}

The descriptive parameters were assessed Into series with numeric values and homoge- 
neous distribution, i.e. measures of central tendency (average, standard deviation, minimum and maximum values of the analysed parameters). Into series with attribute marks, the structural percentages were calculated (relations, proportions). For determination of significant differences, independent sample tests were utilized, depending on data distribution (Chi-square test, Yates corrected Chi-square test, Fisher exact test, Kolmogorov-Smirnov test, t-test for independent samples, Mann-Whitney $U$ test and the difference between two proportions). Values of $p<0.05$ were statistically significant and meaningful, and values of $p<0.01$ were highly significant.

\section{Results}

Basic demographic characteristics of patients are shown in Table 1.

Table 1

\section{Demographical characteristics}

\begin{tabular}{|c|c|c|c|}
\hline $\begin{array}{c}\text { Tab. 1. } \\
\text { Demographical } \\
\text { charasteristics }\end{array}$ & FNB group & FIC group & p-level \\
\hline Age (years) & $79.3 \pm 6.8$ & $76.3 \pm 6.9$ & 0.062 \\
\hline $\begin{array}{c}\text { Gender } \\
\text { men/women }\end{array}$ & $11 / 19$ & $6 / 24$ & 0.25 \\
\hline $\begin{array}{c}\text { Body weight } \\
\text { (kg) }\end{array}$ & $64.2 \pm 10.2$ & $64.3 \pm 8.9$ & 0.97 \\
\hline $\begin{array}{c}\text { ASA status } \\
\text { II, III, IV }\end{array}$ & $5,22,3$ & $8,19,3$ & 0.33 \\
\hline $\begin{array}{c}\text { Duration of } \\
\text { intervention (min) }\end{array}$ & $112.5 \pm 9.2$ & $110.5 \pm 8.2$ & 0.97 \\
\hline Diagnosis p/s/b & $23 / 4 / 3$ & $16 / 2 / 2$ & $>0.05$ \\
\hline p - pertrochanteric, s - subtrochanteric, b - basocervicalis \\
\hline \multicolumn{4}{|l}{}
\end{tabular}

There were no significant differences in distribution of all demographic characteristics between patients in both groups. Both analyzed groups were homogenous taking into consideration all demographic characteristics (Table 1). Female respondents dominated in both groups, $19(63.3 \%)$ in the FNB group, and $24(80 \%)$ in the FIC group This was due to the higher incidence of osteoporosis in women than men.

The analgesia degree among respondents at rest as well as during passive hip flexion up to $1,2,12,24,36$ and 48 hours are shown in Figures 1 and 2 . As can be seen, there is no significant difference in pain relief between the two groups at rest and during passive hip fle- xion in the first 12 hours, or patients from both groups had satisfactory analgesia. One hour after surgery $76.67 \%$ of patients from FNB versus $73.33 \%$ from FIC group were without pain at rest, and after 2 hours, $60 \%$ of patients from both groups $(p>0.05)$. Most of the patients felt moderate pain 12 hours after surgery at rest, $40.0 \%$ from the FNB group versus $43.33 \%$ from the FIC group, and a moderate to severe pain was felt by $23.33 \%$ of patients from both groups $(p>0.05)$. The results were similar during passive hip flexion at the same time intervals: first hour $-60.00 \%$ in the FNB versus $63.33 \%$ in the FIC group without pain, second hour most of the patients felt moderate pain, $63.33 \%$ in the FNB group versus $66.67 \%$ in the FIC group, and after 12 hours, $46.67 \%$ in the FNB versus $43.33 \%$ in the FIC group felt moderate pain and $46.67 \%$ in the FNB versus $50.00 \%$ in the FIC group felt moderate to severe pain $(p>0.05)$.

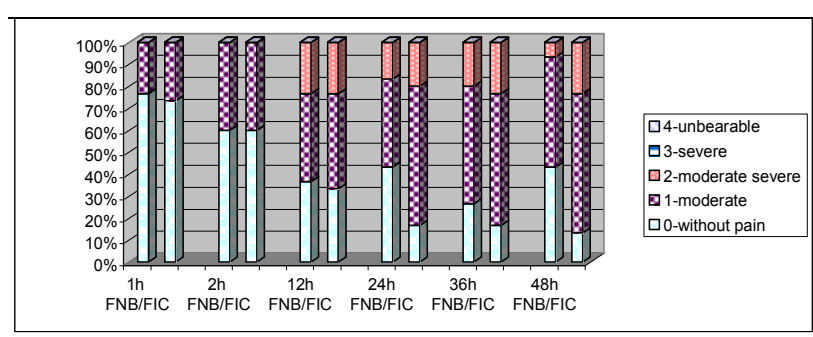

Figure 1-VDS (Verbal descriptive scale) at rest

Mann-Whitney Test

$1 \mathrm{~h} \mathrm{U}=435.0 \mathrm{Z}=0.22 \mathrm{p}$-level $=0.82$

$2 \mathrm{~h} \mathrm{U}=435.0 \quad \mathrm{Z}=0.22 \mathrm{p}$-level $=0.82$

$12 \mathrm{~h} \mathrm{U}=436.0 \mathrm{Z}=0.21 \mathrm{p}$-level $=0.84$

$24 \mathrm{~h} \mathrm{U}=99.5 \quad \mathrm{Z}=5.08 \mathrm{p}$-level $=0.00001$

$36 \mathrm{~h} \mathrm{U}=34.0 \quad \mathrm{Z}=6.15 \mathrm{p}$-level $=0.00001$

$48 \mathrm{~h} \mathrm{U}=21.0 \quad \mathrm{Z}=6.34 \mathrm{p}$-level $=0.00001$

There was a significant difference in pain intensity between patients from the two groups at rest as well as during passive hip flexion up to 24, 36 and 48 hours after surgical intervention $(p<0.001)$. At these time intervals, a much larger number of patients from the FNB group were registered without pain in comparison to respondents from the FIC group (at rest $43.33 \%$ in FNB vs $16.67 \%$ in FIC after 24 hours, $26.67 \%$ in FNB vs $16.67 \%$ in FIC after 36 hours and $43.33 \%$ in FNB vs $13.33 \%$ in FIC after 48 hours). Also, the pain was more often of severe intensity during passive hip flexion among respondents from the FIC group compared with respondents from the FNB group (severe pain felt by $56.66 \%$ in FIC vs $3.33 \%$ in 
FNB after 24 hours, $46.67 \%$ in FIC vs $0 \%$ in FNB after 36 hours and $40 \%$ in FIC vs $6.67 \%$ in FNB after 48 hours during passive hip flexion).

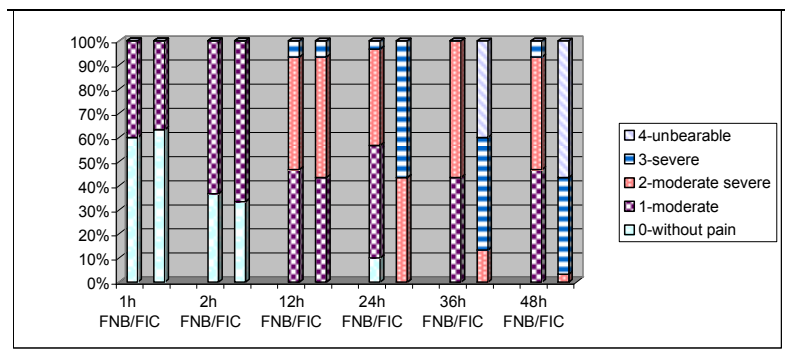

Figure 2 - VDS (verbal descriptive scale) during passive hip flexion

Mann-Whitney test

$1 \mathrm{~h} \mathrm{U}=435.0 \mathrm{Z}=0.22 \mathrm{p}$-level $=0.82$

$2 \mathrm{~h} \quad \mathrm{U}=450.0 \mathrm{Z}=0.00 \mathrm{p}$-level $=1.0$

$12 \mathrm{~h} \mathrm{U}=438.0 \mathrm{Z}=0.17 \mathrm{p}$-level $=0.86$

$24 \mathrm{~h} \mathrm{U}=237.5 \mathrm{Z}=3.14 \mathrm{p}$-level $=0.0017$

$36 \mathrm{~h} \mathrm{U}=0.0 \quad \mathrm{Z}=6.65 \mathrm{p}$-level $=0.00001$

$48 \mathrm{~h} \mathrm{U}=281.5 \mathrm{Z}=2.49 \mathrm{p}$-level $=0.013$

Table 2 presents the first time when the patients in the two groups requested additional analgesia.

Table 2

First addition of analgesic agent

\begin{tabular}{|c|c|c|c|c|c|}
\hline $\begin{array}{c}\text { First added analgesic } \\
\text { agent (hours) }\end{array}$ & $\mathrm{N}$ & mean & SD & Min. & Max. \\
\hline FNB group & 30 & 12.58 & 0.8 & 11.3 & 14 \\
\hline FIC group & 30 & 11.98 & 1.05 & 9.45 & 14 \\
\hline
\end{tabular}

There was a statistically highly significant difference in the time of the first additionally introduced analgesic agent between two groups (after 12. 58 hours for the FNB group versus 11. 98 hours for FIC group) $(p=0.018)$.

Table 3

Additional analgesia with tramadol

\begin{tabular}{|c|c|c|c|c|c|c|c|c|}
\hline \multirow{3}{*}{$\begin{array}{l}\text { tramadol } \\
\text { (mg/kg bw) }\end{array}$} & \multicolumn{4}{|c|}{ POD 1} & \multicolumn{4}{|c|}{ POD 2} \\
\hline & \multicolumn{2}{|c|}{ FNB } & \multicolumn{2}{|c|}{ FIC } & \multicolumn{2}{|c|}{ FNB } & \multicolumn{2}{|c|}{ FIC } \\
\hline & $\mathrm{N}$ & $\%$ & $\mathrm{~N}$ & $\%$ & $\mathrm{~N}$ & $\%$ & $\mathrm{~N}$ & $\%$ \\
\hline 0 & 25 & 83.33 & 25 & 83.33 & 23 & 76.67 & 0 & 0 \\
\hline 1 & 5 & 16.67 & 5 & 16.67 & 7 & 23.33 & 15 & 50 \\
\hline 1.5 & 0 & 0 & 0 & 0 & 0 & 0 & 9 & 30 \\
\hline 2 & 0 & 0 & 0 & 0 & 0 & 0 & 6 & 20 \\
\hline 2.5 & 0 & 0 & 0 & 0 & 0 & 0 & 0 & 0 \\
\hline Total & 30 & 100 & 30 & 100 & 30 & 100 & 30 & 100 \\
\hline & & & & & & are $=41$. & 2 & 0000 \\
\hline
\end{tabular}

Additional analgesia with tramadol during the first and second postoperative days (POD 1 and POD 2) is shown in Table 3 . There was no significant difference in additionally applied tramadol during the first postoperative day between patients from the two groups $(83.33 \%$ of patients from both groups received $1 \mathrm{mg} / \mathrm{kg}$ bw and $16.67 \%$ of patients $1.5 \mathrm{mg} / \mathrm{kg} \mathrm{bw}$ ).

Regarding the second postoperative day, 7 participants from the FNB group and all participants from the FIC group were additionally given tramadol. A dose of $1 \mathrm{mg} / \mathrm{kg} \mathrm{BW}$ tramadol was given to $7(23.3 \%)$ patients from the FNB group, and to half of the patients from the FIC group, $15(50 \%)$. Nine (30\%) patients from the FIC group received $1.5 \mathrm{mg} / \mathrm{kg} \mathrm{BW}$, and the remaining $6(20 \%) 2 \mathrm{mg} / \mathrm{kg} \mathrm{BW}$. Patients with fascia iliaca compartment received higher doses of analgesia with tramadol during the second postoperative day in comparison with those with femoral nerve blockade $(\mathrm{p}<$ 0.00000) (Table 3).

Administration of an analgesic agent for analgesia to a certain number of patients provoked unwanted side-effects such as nausea, sedation, and dizziness (Figure 4). Nausea occurred in $30 \%$ of the FNB patients and in $26.7 \%$ of the FIC patients. Sedation was also noted in $30 \%$ of respondents in the FIC group, and in $13.3 \%$ of respondents in the FNB group. About $30 \%$ of respondents from the FIC group complained of dizziness.

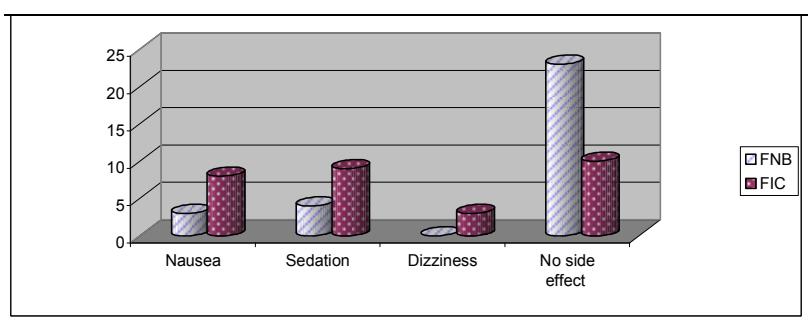

Figure 3 - Side-effects after administration of analgesic agent

Analgesia which was done with a fascia iliaca compartment block significantly more often resulted in nausea and dizziness $(p<0.05)$ compared to analgesia with a femoral nerve block.

\section{Discussion}

The results of the study indicate that peripheral nerve blocks improve analgesia in patients after surgical treatment of hip fracture. Continuous FNB block provided superior analgesia compared to FIC block [25] in the three last tested standby periods, as well as during 
the patient's hip flexion, and much smaller amounts of additional analgesia in patients who were treated with continuous FNB block. There was no significant difference in the degree of analgesia in the two groups in the first and second postoperative hour, as well as 12 hours after surgery, during rest and during hip flexion. There are a few studies on the effect of single and continuous FNB block as a perioperative analgesia in patients with hip fracture $[13,15,16,18,19]$. Sirvastativa et al. [15] investigated the single FNB block versus psoas compartment block as an analgesia after hip surgery. The author and his associates have come to the conclusion that there is no clinically significant difference between the two blocks in terms of the effect of postoperative analgesia during resting periods and during physiotherapy practice, as well as in terms of time and the amount of additional analgesia. The single FNB block improves the quality of postoperative analgesia in the first 12 hours after surgery and allows for early commencement of physical therapy, but already 24 hours after surgery, a higher proportion of patients felt severe pain.

Salinas et al. [17] compared the analgesic effect of a single versus continuous FNB block in the course of 48 hours in patients after total knee artroplastics. The results they obtained were similar to the results we obtained in our study: the values for the VAS score (verbal analogue scale) were lower in patients with a continuous FNB block versus the values of VAS score in patients with a single FNB block, at rest and during performance of physical therapy, especially the second day after surgery, as well as by adding small amounts of additional analgesics. However, the study showed that although a continuous femoral nerve block has a prolonged analgesic effect in relation to the unit block of the femoral nerve, it does not affect the length of hospital stay of patients. We did not study the duration of hospital stay, which in fact is a limitation of this study.

In the study by Monzon et al. [10] which assessed the analgesic effect of a single FIC block versus systemic non-steroidal analgesia in patients with hip fractures, it was confirmed that a group of block pain-released patients requested additional analgesia less and much later than the group of patients who received sys- temic analgesia. The FIC block had a quick onset and it provided excellent pain relief up to 8 hours.

Fascia iliaca compartment block in studies by Foss et al. [20], Candal-Couto et al. [21], Hogh et al. [22] and Hanna et al. [26] was evaluated only as a preoperative analgesia technique in patients with hip fractures, and they came to the conclusion that this block is a simple, inexpensive and effective method for preoperative analgesia. Candal-Couto et al. [21] found that patients with a block as the choice of preoperative analgesia have had a lower VAS scale, especially when sitting and in passive hip flexion, compared to those with systemic analgesia. The author and his associates come to the conclusion that patients with peripheral block do sit in bed more comfortably while waiting for surgery.

Foss et al. [20], Hogh et al. [22] and Hanna et al. [26], besides the analgesic effect of the fascia iliaca compartment block, have examined the amount of additional analgesia (morphine) in patients with hip fracture while waiting for surgical procedure. Patients with fascia iliaca compartment block received no morphine, since there was no pain, whereas patients who received systemic analgesia received significantly higher amounts of morphine. Hogh et al. [22] and Hanna et al. [26] have estimated that this block is simple to perform, requires minimal training, and is also an effective substitute for conventional treatment of pain in elderly patients with hip fractures. In their studies, FIC block was performed by junior registrars.

The only study in which the fascia iliaca compartment block was used for postoperative analgesia as a continuous technique is the Cuignet et al. [24] study which used the continuous block analgesia in patients with burns and for taking graft from the femoral area. The effect of the block was assessed with the VAS scale particularly preoperatively, 24 and 48 hours post-operatively, and during the first bandage change at 72 hours post-operatively. The control group were patients treated with intravenous opioid analgesics. Results achieved for VAS scale values were similar to those in the studies made by Foss et al. [20], CandalCouto et al. [21], Hogh et al. [22] and Hanna et al. [26], and at the same time coincide with the 
results of our study, i.e. showed that fascia iliaca compartment block pain-released patients had significantly more effective analgesia. Effectiveness of analgesia was proved with a smaller amount of nonopiod analgesics given additionally to patients with continuous peripheral block, as opposed to those with systemic analgesia. Opioid analgesics were not added in the case of patients with continuous peripheral block.

Newman et al. [25] compared preoperative analgesia with single femoral nerve block versus single fascia iliaca compartment block in patients with a femoral neck fracture and concluded that both blocks provide analgesia up to 12 hours, but FNB block analgesia is superior in comparison with analgesia provided by fascia iliaca compartment block and patients with femoral nerve block received less analgesic agents.

In our study fascia iliaca compartment block was used as a single block post-operative analgesia. It provided effective analgesia, but only in the first 12 hours of the post-operative period. That is why the amount of additional analgesia with opioid analgesics during the first postoperative day (POD 1) showed an insignificant difference between the two groups of patients (FNB and FIC groups). Patients with FNB block, which was used as a continuous block the second postoperative day (POD 2), received significantly smaller amounts of opioid analgesics, compared to patients with FIC block.

In all studies demonstrating unwanted consecutive side-effects, such as studies by Layzell [16], Beaudoin [19], Foss et al. [20] and Cuignet et al. [24], there were no recorded side-effects such as haematoma, infection, and paraesthesia which are also the most common adverse consecutive side effects of nerve blocks. In none of these studies was a systemic toxic effect of applied local anaesthetic registered. Nausea, vomiting and sedation were registered in a higher percentage of patients with systemic analgesia. In our study, from all monitored side consecutive actions, only nausea, dizziness and sedation were registered, and in a significantly higher percentage in the FIC group, because the FIC block was performed as a single block and it provided analgesia only during the first 12 hours after intervention. Furthermore, in the postoperative period, patients in this group requested high amounts of additional analgesia.

Our random selection programme did not fully succeed in creating two comparable groups, because in both groups there was a significantly higher proportion of women than men and this is an additional limitation of our study. Gender difference is interpreted with the knowledge that hip fractures are more common in women due to frequent osteoporosis, the main risk factor for these fractures, as defined in the study by Parker et al. [1]. This gender difference should not interfere with the results, because the requests for analgesia are not ageor gender-dependant, which was elaborated in the Aubrun et al. [21] study.

\section{Conclusions}

1. Continuous femoral nerve block provides effective and prolonged postoperative analgesia until the patient feels pain. 2. Patients with continuous femoral nerve block received smaller amounts of additional analgesic agents and had fewer side-effects compared to patients with simple fascia iliaca compartment block. 3 . The single fascia iliaca compartment block resulted in pain relief up to 12 hours after the procedure.

\section{REFERENCES}

1. Parker M, Johansen, A. Hip fracture. British Medical Journal. 2006; 333: 7557, 27-30.

2. Bottle A, Aylin, P. Mortality associated with delay in operation after hip fracture: observational study. British Medical Journal. 2006; 332: 947-951.

3. Bruckenthal P, D'Arcy Y. Assessment and management of pain in older adults: A review of the basics. Topics in Advanced Practice Nursing eJournal. 2007; 7: 1 .

4. Myles PS, Power I. Clinical update: postoperative analgesia. The Lancet. 2007; 369, 810-812.

5. Grant CRK, Chetketts MR. Analgesia for primary hip and knee arthroplasty: the role of regional anesthesia. Br J Anesth: CEACCP. 2008; 8: 56-61.

6. Kehlet H, Dahl JB. Anesthesia, surgery and challenges in postoperative recovery. Lancet. 2003; 362: 1921-8.

7. Aubrun F, Salvi N, Coriat P, Riou B. Sex- and agerelated differences in morphine requirements for postoperative pain relief. Anesthesiology. 2005; 103: 156-60.

8. ER. Viscusi and M. Pappagallo. A review of opioids for in-hospital pain management. Hospital Practice. 2012; 40(1): 149-159. 
9. White PF. The role of non-opioid analgesic techniques in the managment of pain after ambulatory surgery. Anesth Analg. 2002; 94: 577-85.

10. DG. Monzón, J. Vazquez, J. R. Jauregui, and K. V. Iserson. Pain treatment in post-traumatic hip fracture in the elderly: regional block versus systemic nonsteroidal analgesics. International Journal of Emergency Medicine. 2010; 3(4): 321-325.

11. Liu SS, Wu ChL. The effect of analgesic technique on postoperative patient - reported outcomes including analgesia: a systematic review. Anesth Analg. 2007; 105: 789-808.

12. Capdevila $X$, et al. Continuous peripheral nerve blocks in hospital wards after orthopedic surgery: a multicenter prospective analysis of the quality of postoperative analgesia and complications in 1416 patients. Anesthesiology. 2005; 103: 1035-45.

13. Biboulet P, Moran D, Aubas P. Bringuier-Brancheren, Capdevila X. Postoperative analgesia after total hip arthroplasty; comparison of IV Patient controlled analgesia with morphine and single injection of femoral nerve or psoas compartment block. A prospective randomized double blind study. Reg Anesth Pain Med. 2004; 29: 102-09.

14. Grant CRK, Chetketts MR. Analgesia for primary hip and knee arthroplasty:the role of regional anesthesia. Br J Anesth: CEACCP. 2008; 8: 56-61.

15. Srivastava U, Kumar A, Saxena S, et al. Lumbar plexus block for post - operative analgesia following hip surgery: a comparison of " 3 in 1" and psoas compartment block. Indian J Anesth. 2007; 51: 127-130.

16. Layzell MJ. Use of femoral nerve blocks in adults with hip fractures. Nurs Stand. 2013; 3; 27(52): 4956.

17. Salinas VF, Liu SS, Milroy FM. The effect of singleinjection femoral nerve block versus continuous femoral nerve block after total knee arthroplasty on hospital length of stay and long-term functional recovery within an established clinical pathway. Anesth Analg. 2006; 102: 1234-1239.

18. Szilard Szucs, Gabriella Iohom, Brian O'Donnell, et al. Analgesic efficacy of continuous femoral nerve block commenced prior to operative fixation of fractured neck of femur. Perioperative Medicine. 2012; 1: 4.

19. Beaudoin FL, Haran JP, Liebmann O. A comparison of ultrasound-guided three-in-one femoral nerve block versus parenteral opioids alone for analgesia in emergency department patients with hip fractures: a randomized controlled trial. Acad Emerg Med. 2013; 20(6): 584-91.

20. Foss, Nicolai B, Kristensen B, et al. Fascia iliaca compartment blockade for acute pain control in hip fracture patients: A randomized, placebo-controlled trial. Anesthesiology. 2007; 106: 773-78.

21. Candal-Couto JJ, McVie JL, Haslam N, Innes AR, Rushmer J. Pre-operative analgesia for patient with femoral neck fractures using a modified fascia iliaca block technique. Injury. 2005; 36: 505-10.

22. Hogh A, Dremstrup L, Skov Jensen S, and Lindholt J. Fascia iliaca compartment block performed by junior registrars as a supplement to pre-operative analgesia for patients with hip fracture. Strategies Trauma Limb Reconstr. 2008; 3: 65-70.

23. E. Dulaney-Cripe, S. Hadaway, R. Bauman et al. A continuous infusion fascia iliaca compartment block in hip fracture patients: a pilot study. Journal of Clinical Medicine Research. 2012; 4(1): 45-48.

24. Cuignet O, Pirson J, Boughrouph J, Duville D. The efficacy of continuous fascia iliaca compartment block for pain management in burn patients undergoing skin grafting procedures. Anesth Analg. 2004; 98: 1077-81.

25. Newman B, McCarthy L, Thomas PW, May P, Layzell M, Horn K. A comparison of pre-operative nerve stimulator-guided femoral nerve block and fascia iliaca compartment block in patients with a femoral neck fracture. Anaesthesia. 2013; 68: 899-903.

26. L. Hanna, A. Gulati, and A. Graham. The Role of Fascia Iliaca Blocks in Hip Fractures: A Prospective Case-Control Study and Feasibility Assessment of a Junior-Doctor-Delivered Service. ISRN Orthopedics 2014; Article ID 191306, 5 pages.

Резиме

\section{КОНТИНУИРАН БЛОК НА ФЕМОРАЛЕН НЕРВ НАСПРОТИ FASCIA ILIACA COMPARTMЕNT БЛОК КАКО ПОСТОПЕРАТИВНА АНАЛГЕЗИЈА КАЈ ПАЦИЕНТИ СО СКРШЕНИЦА НА КОЛК}

\author{
Марина Темелковска-Стевановска ${ }^{1}$, \\ Весна Дурнев ${ }^{1}$, Марија Јовановски-Срцева ${ }^{1}$, \\ Маја Мојсова-Мијовска ${ }^{1}$, Симе Трпески ${ }^{2}$ \\ ${ }^{1}$ Универзитетска клиника за анестезија, \\ реанимација и интензивно лекување, \\ Медицински факултет, Универзитет „Св. Кирил \\ и Методиј“, Скопје, Р. Македонија \\ 2 Универзитетска клиника за трауматологија, \\ Медицински факултет, Универзитет „Св. Кирил \\ и Методиј“, Скопје, Р. Македонија
}

Вовед: Системската аналгезија во постоперативниот период е незадоволителна кај најголем број пациенти со скршеница на колк, што претставува причина за болка, особено при обид да ја движат повредената нога. Блоковите на периферните нерви и плексуси претставуваат ефективна опција за постоперативно обезболување.

Целта на оваа студија беше да се испита квалитетот на континуиран блок на феморалниот нерв наспроти единечен fascia iliaca compartment блок како постоперативна аналгезија кај постари пациенти со скршеница на колк. 
Майеријал и мейоди: Во оваа студија беа опфатени 60 пациенти со скршеница на колк и беа рандомизирано поделени во две групи по 30 пациенти: група FNB-пациенти со континуиран блок на феморалниот нерв и група FIC-пациенти со единечен fascia iliaca compartment блок. Кај сите пациенти се одредуваше степенот на аналгезија со Вербалната дескриптивна скала (VDS, 0-4), во периодот од 1, 2, 12, 24, 36 и 48 часа постоперативно, при мирување и при пасивна флексија на колкот. Беше регистрирана и количината на дополнителната аналгезија и времето кога прв пат пациентот ја побарал, како и несаканите проследени ефекти.

Резулйайи: Ова истражување покажа дека вредностите на VDS се сигнификантно пониски кај пациентите од групата FNB наспроти групата FIC, при мирување, како и при пасивна флексија на колкот, и тоа 24 часа постоперативно (46,67\% испитаници од групата FNB имале умерена болка наспроти 0\% од групата FIC), 36 часа постоперативно (43,33\% од FNB наспроти $0 \%$ од FIC имале умерена болка) и 48 часа по интервенцијата (46,67\% од FNB наспроти 3,33\% од FIC имале средно јака болка), за $\mathrm{p}<0,05$. Пациентите од групата FNB примаа сигнификантно помала количина дополнителна аналгезија наспроти оние од групата FIC (23,3\% наспроти $50 \%$, за $\mathrm{p}<0,05)$. Од несакани дејства беа регистрирани само гадење, вртоглавица и седација, статистички сигнификантно почести во групата FIC, за $\mathrm{p}<0,05$.

Заклучоци: Континуиран блок на феморалниот нерв обезбедува супериорна аналгезија наспроти единечен fascia iliaca compartment блок, како при мирување, така и при движење кај пациентите со скршеница на колк.

Клучни зборови: постоперативна аналгезија; регионална анестезија; fascia iliaca compartment block; блок на феморален нерв; фрактури на колк. 